\title{
Peran Guru dalam Mengembangkan Karakter Peserta Didik
}

\author{
Indah Fauziah* \\ E-mail: fauziahindah402@gmail.com \\ *Program Studi Pendidikan Bahasa dan Sastra Indonesia, Universitas Riau
}

\section{Pengantar}

Dalam dunia pendidikan, pasti tidak akan terlepas dengan adanya tugas atau peran seorang guru terhadap anak muridnya. Di mana sosok seorang guru sangat dibutuhkan demi terciptanya karakter atau kepribadian peserta didiknya. Hal ini membuat para guru untuk bekerja keras dan meluangkan waktunya untuk mencapai tugas tersebut. Oleh sebab itu, guru sebagai sosok utama dalam pendidikan yang memiliki peran penting dalam mendidik serta membimbing peserta didik menjadi manusia yang cerdas dan mempunyai akhlak maupun karakter yang terpuji.

(Hardiyana, 2014) mengemukakan bahwa guru memegang peranan penting dalam sebuah proses belajar mengajar. Oleh sebab itu, kualitas pendidikan di suatu sekolah sangat ditentukan oleh kemampuan yang dimiliki seorang guru dalam melaksanakan tugasnya. Guru ialah orang tua siswa dalam lingkungan sekolah. Untuk itu peran guru sangat berarti dalam membentuk kepribadian peserta didik selain di lingkungan sekolah. Lebih lanjut, ia mengemukakan bahwa pada kenyataan yang terjadi, pada dunia pendidikan hanya memberikan aspek intelektual atau pengetahuan tanpa memperhatikan aspek emosional dan spiritual, serta hanya terjadi bentuk-bentuk kenakalan dikalangan remaja yang hanya dapat merugikan dirinya sendiri dan juga lingkungan di sekitarnya. Oleh karena itu, peran guru sangat penting dalam mengembangkan karakter yang baik kepada peserta didik.

\section{Guru}


Guru adalah sosok yang begitu dihormati karena memiliki tugas yang cukup besar terhadap keberhasilan pembelajaran di sekolah. Guru sangat berperan dalam membantu perkembangan peserta didik untuk mencapai kemampuan dan karakter yang optimal, serta mempunyai tanggung jawab untuk membimbing dan membina murid (Hamid, 2017).

Dalam mengembangkan karakter setiap peserta didiknya, guru juga dituntut memiliki kepribadian yang baik dan profesional. Di mana diungkapkan oleh (Mulyasa, 2005) bahwa guru yang profesional adalah guru yang memiliki: (1) Kompetensi pedagogik, yaitu kemampuan yang berkenaan dengan pemahaman siswa dan pengelola pembelajaran yang mendidik, yang mencakup kemampuan perancangan dan pelaksanaan pembelajaran, evaluasi hasil belajar, dan pengembangan siswa untuk mengaktualisasikan berbagai potensi yang dimilikinya. (2) Kompetensi kepribadian, yaitu kemampuan personal yang mencerminkan kepribadian yang mantap, stabil, dewasa, arif, dan berwibawa, menjadi teladan bagi peserta didik, dan berakhlak mulia. (3) Kompetensi sosial, yakni berkenaan dengan kemampuan guru sebagai bagian dari masyarakat untuk berkomunikasi secara efektif dengan siswa, warga sekolah dan juga masyarakat.

Menurut (Bhakti \& Maryani, 2016) guru adalah salah satu jabatan profesional dalam bidang kependidikan. Sebagai jabatan, guru harus disiapkan melalui pendidikan dalam jangka waktu tertentu dengan seperangkat mata kuliah tertentu sesuai dengan jenjangnya. Sedangkan menurut (Wardana, 2013) guru adalah komponen yang paling menentukan dalam sistem pendidikan secara keseluruhan, yang harus mendapat perhatian sentral, pertama, dan utama, serta sebagai sumber daya manusia yang menjadi perencanaan, pelaku dan penentu tercapainya tujuan pendidikan.

\section{Peran Guru}

Guru memiliki peran yang sangat penting dalam proses pendidikan, terutama dalam memberikan teladan yang baik bagi pengembangan karakter peserta didiknya. Peran yang dimaksud di sini adalah bahwa peran utama guru 
dalam pendidikan karakter yang pertama yaitu keteladanan. Keteladanan adalah salah satu faktor yang harus dimiliki oleh guru. Keteladanan yang dibutuhkan guru berupa konsistensi dalam menjalankan perintah dan menjauhi larangan-Nya. Hal ini seperti yang diungkapkan oleh (Palunga \& Marzuki, 2017) bahwa guru adalah teladan dan contoh bagi anak didiknya. Guru memiliki komitmen terhadap aturan yang ada, menghargai orang lain, dan memiliki komitmen dengan sikap, tingkah laku, tindakan, dan ucapannya di lingkungan sekolah atau di luar sekolah. Selain itu, guru juga memberikan motivasi kepada peserta didik untuk patuh pada aturan sekolah.

Sebagai pendidik, guru lebih banyak menjadi sosok panutan yang mempunyai karakter atau kepribadian yang patut ditiru dan diteladani oleh peserta didik. Contoh keteladanan itu lebih mengarah kepada sikap dan perilaku seperti, bertanggung jawab, menghargai orang lain, tekun, rendah hati, jujur, dan sopan santun terhadap sesama. Sikap dan perilaku guru sehari-hari dapat diteladani oleh peserta didik, baik di dalam maupun di luar kelas, merupakan suatu alat pendidikan yang diharapkan akan membentuk karakter atau kepribadian peserta didik kelak jika dewasa. Oleh karena itu, guru dipandang sebagai role model yang akan digugu dan ditiru oleh peserta didiknya (Suparlan, 2005).

Adapun menurut (Barnawi \& Arifin, 2012) peran guru sebagai teladan adalah guru yang dapat menjadi role model, yaitu yang dapat digugu dan ditiru oleh peserta didiknya. Oleh sebab itu, guru melaksanakan lima peran, diantaranya: 1) sebagai pemelihara sistem nilai yang merupakan sumber norma kedewasaan;2) sebagai pengembang sistem nilai ilmu pengetahuan; 3) sebagai penerus sistem nilai ini kepada peserta didik; 4) sebagai penjelmaan dalam pribadinya dan perilakunya, dalam proses interaksi dengan sasaran didik; 5) sebagai penyelenggara terciptanya proses edukatif yang dapat dipertanggung jawabkan, baik secara formal (kepada pihak yang mengangkat dan menugaskannya) maupun secara moral (kepada sasaran didik, serta Tuhan yang menciptakannya). Oleh karena itu, peran guru dalam mengembangkan karakter peserta didik sangatlah penting. Di mana guru adalah agen moral, yang merupakan sosok yang bermoral 
dan memiliki atau menunjukkan perilaku atau karakter serta contoh yang baik kepada peserta didiknya, melalui sikap, tutur kata, dan juga tingkah lakunya.

Guru juga memiliki peran sebagai pendidik, di mana pendidik dalam (UU No. 20 Tahun 2003 Tentang Sistem Nasional Pendidikan) didefinisikan dengan tenaga kependidikan yang berkualifikasi sebagai guru, dosen, konselor, tutor, instruktur, fasilitator, dan sebutan lain yang sesuai dengan kekhususannya, serta berpartisipasi dalam menyelenggarakan pendidikan. Undang-Undang Nomor 20 Tahun 2003, Bab XI Pasal 39 Ayat 2 menyatakan bahwa Guru sebagai pendidik adalah tenaga profesional yang bertugas merencanakan dan melaksanakan proses pembelajaran, menilai hasil pembelajaran, melakukan pembimbingan dan pelatihan serta melakukan penilitian dan pengabdian kepada masyarakat.

Peran guru sebagai pendidik erat kaitannya dengan pengembangan karakter peserta didik, di mana guru bertugas memberikan bantuan dan dorongan, pengawasan dan pembinaan, serta tugas yang berkaitan dengan mendisiplinkan anak agar anak menjadi patuh terhadap aturan-aturan sekolah dan norma hidup dalam keluarga dan masyarakat. Sehingga pertumbuhan dan perkembangan karakter anak dapat diupayakan untuk memperoleh pengalaman-pengalaman yang lebih lanjut (Juhji, 2016). Selain sebagai pendidik dalam mengembangkan karakter, guru juga berperan sebagai pengajar dan pembimbing, artinya guru yang membantu pengembangan intelektual, afeksi dan psikomotor melalui penyampaian pengetahuan, pemecahan masalah latihan-latihan afektif dan keterampilan. Dengan ini, guru diharapkan dapat menanamkan karakter berupa sikap cerdas, terampil dan bersungguh-sungguh (Sukmadinata, 2007).

Dalam menjalankan perannya, yakni sebagai pendidik, pengajar, maupun pembimbing, guru dapat membentuk sikap individu sebagai pembelajar yang bertanggung jawab dan mampu mengimplementasikan ilmunya demi kebaikan diri dan sesama. Sehingga, tanggung jawab moral guru sebagai pendidik, pengajar, maupun pembimbing adalah membangun pondasi dasar ilmu pengetahuan, menumbuhkan keterampilan dan kemampuan berpikir kritis 
sehingga peserta didik mampu memahami persoalan dan dapat menyelesaikan persoalan dengan ilmu yang dimilikinya, dengan mengedepankan setiap karakter masing-masing peserta didik (Ansori, 2018).

Untuk membangun peserta didik sebagai sosok yang berkarakter, guru dapat melaksanakan empat hal yang harus dilakukan. Seperti yang diungkapkan oleh (Hakam, 2013), bahwa untuk membangun individu sebagai sosok yang berharga, berkarakter, dan juga bermartabat dapat dilaksanakan melalui empat hal. Pertama, melalui keteladanan, artinya setiap langkah awal siapapun harus belajar moral dan karakter melalui percontohan, dan dalam mencontoh diperlukan sosok yang patut dicontoh, guru dituntut untuk menjadi panutan dan pribadi yang menampilkan nilai-nilai moral. Kedua, melalui pembiasaan, artinya perilaku baik perlu dibiasakan, bukan merupakan pilihan, tetapi menjadi suatu keharusan. Pembiasaan perbuatan baik harus terus menerus bukan situasional. Terjadinya inkonsistensi perbuatan moral, sering mendorong peserta didik untuk memilih tindakan immoral. Sehingga diperlukan adanya suasana yang kondusif di sekolah agar nilai moral dapat teramalkan dalam setiap tindakannya. Ketiga, melalui sosialisasi, artinya menyampaikan nilai moral pada publik, baik melalui pengajaran, ceramah, khotbah, slogan, simbolisasi, berita, yang sifatnya selalu mengingatkan individu agar berbuat kebaikan. Dan yang keempat, membangun motivasi moral, artinya menghadapkan individu atau kelompok pada sejumlah pilihan yang sifatnya dilematis. Dilema moral inilah untuk mengokohkan prinsip moral yang telah ada pada diri individu, sehingga akan tetap konsisten untuk berlaku kebajikan.

Dalam mengembangkan karakter peserta didik, guru juga dituntut untuk memiliki peran sebagai motivator dalam kegiatan pembelajaran. Di mana guru bersikap terbuka, yakni guru harus melakukan tindakan yang mampu mendorong kemauan murid untuk mengungkapkan pendapatnya, menerima siswa dengan segala kekurangan dan kelebihannya, menunjukkan perhatian terhadap permasalahan yang dihadapi siswa, dan juga menunjukkan sikap ramah serta pengertian terhadap siswa. Selain itu, guru membantu siswa agar mampu 
memahami dan memanfaatkan potensi yang ada pada dirinya secara optimal, dalam arti guru harus mampu memberikan gambaran tentang kemampuan dan kelemahan para siswanya, membantu siswa agar memiliki rasa percaya diri dan memiliki keberanian dalam membuat keputusan. Sehingga, dalam proses pembelajaran akan berhasil manakala peserta didik memiliki motivasi dalam belajar. Oleh karena itu, guru perlu menumbuhkan dan membangkitkan motivasi belajar siswa, sehingga terbentuk karakter belajar siswa yang efektif (Manizar, 2015).

\section{Penutup}

Guru merupakan sosok individu yang memiliki peran yang sangat penting dan utama dalam dunia pendidikan, terutama dalam mengembangkan karakter setiap peserta didiknya. Salah satu peran guru adalah sebagai bentuk keteladanan, dengan keteladanan maka setiap karakter yang dicontohkan oleh guru, akan digugu dan juga ditiru oleh peserta didiknya. Kemudian, peran guru yang lainnya adalah sebagai pendidik, pengajar, maupun pembimbing yang diwujudkan untuk memperbaiki dan meningkatkan karakter diberbagai aspek, diantaranya aspek kognisi, aspek afeksi, dan aspek psikomotor. Hal itu semua dapat dilengkapi oleh peran guru sebagai motivator dalam pendidikan, karena dengan adanya motivasi yang baik dari guru, maka karakter belajar siswa akan terbentuk secara efektif. Sehingga, untuk membentuk dan mengembangkan karakter setiap peserta didiknya, gurulah yang berperan aktif dalam hal tersebut.

\section{Referensi}

Ansori, Y. Z. (2018). Menumbuhkan Karakter Baik Melalui Peranan Guru di Sekolah. Jurnal Cakrawala Pendas, 4(2), 83-90. https://doi.org/10.31949/jcp.v4i2.1497

Barnawi, \& Arifin, M. (2012). Strategi \& Kebijakan Pembelajaran Pendidikan Karakter. Yogyakarta: Ar-Ruzz Media.

Bhakti, C. P., \& Maryani, I. (2016). Strategi LPTK dalam Pengembangan Kompetensi Pedagogik Calon Guru. Jurnal Pendidikan, 1(2), 98-106. https://doi.org/10.26740/jp.v1n2.p98-106

Hakam, K. A. (2013). Pendekatan Pendidikan Karakter di Sekolah Dasar. UPI: 


\section{Bandung}

Hamid, A. (2017). Guru Profesional. Al Falah, XVII(32), 274-285.

Hardiyana, S. (2014). Pengaruh Guru PKn Terhadap Pembentukan Karakter Siswa. JURNAL ILMIAH PPKn IKIP VETERAN SEMARANG, 2(1), 54-64.

Juhji. (2016). Peran Urgen Guru dalam Pendidikan. Studia Didaktika: Jurnal Ilmiah Pendidikan, 10(1), 52-62.

Manizar, E. (2015). Peran Guru Sebagai Motivator dalam Belajar. Tadrib, 1(2), $171-188$.

Mulyasa, E. (2005). Menjadi Guru Profesional. Bandung: PT Remaja Rosdakarya.

Palunga, R., \& Marzuki. (2017). Peran Guru dalam Pengembangan Karakter Peserta Didik di Sekolah Menengah Pertama Negeri 2 Depok Sleman. Jurnal Pendidikan Karakter, VII(1), 109-123. https://doi.org/10.21831/jpk.v7i1.20858

Sukmadinata, N. S. (2007). Landasan Psikologi Proses Pendidikan. Bandung: Remaja Rosdakarya.

Suparlan. (2005). Menjadi Guru Efektif. Yogyakarta: Hikayat.

UU No. 20 Tahun 2003 tentang Sistem Nasional Pendidikan.

Wardana, D. S. (2013). Motivasi Berprestasi dengan Kinerja Guru yang Sudah Disertifikasi. Jurnal Ilmiah Psikologi Terapan, 01(01), 98-109. http://ejournal.umm.ac.id/index.php/jipt/article/viewFile/1361/1456 
*Data Penulis

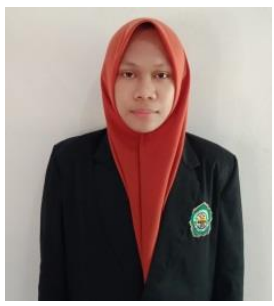

Indah Fauziah, lahir di Siak, 3 Desember 2001. Ia tamat dari MAS Al Muttaqien pada tahun 2020 dan Ia melanjutkan studi pada strata satu Jurusan Pendidikan Bahasa dan Seni di Program Studi Pendidikan Bahasa dan Sastra Indonesia FKIP Universitas Riau melalui jalur SNMPTN (Seleksi Masuk Perguruan Tinggi Negeri). Sekarang Ia sedang menempuh pendidikannya pada semester tiga di kampus tercinta.

Kontak:

Hp/WA : +6282269144648

Email : fauziahindah402@gmail.com 